\title{
Ampicillin serum levels and treatment results in gonorrhoea
}

\author{
GUNNEL ERIKSSON \\ Department of Dermatology, Södersjukhuset, Stockholm, Sweden
}

Recent studies have proved that the treatment of uncomplicated gonorrhoea with oral ampicillin, administered either in a single dose of $2 \mathrm{~g}$. plus $1 \mathrm{~g}$. probenecid or $2 \mathrm{~g}$. divided into two doses at an interval of $5 \mathrm{hrs}$, is an effective alternative to the conventional treatment with a single intramuscular injection of 2.2 m.u. penicillin G (Eriksson, 1970a,b, 1971a). To find out if there is any correlation between therapeutic failure, the minimum inhibitory concentration (MIC) for N. gonorrhoeae, and serum levels of ampicillin, a clinical trial was performed in patients treated for uncomplicated gonorrhoea with the dosage schedules for oral ampicillin used earlier. It was also considered to be of interest to carry out serial estimates of the antibiotic serum level and bacterial cultures during the first day of treatment in patients hospitalized for recurrent gonococcal infections despite repeated treatment, or for complications of the disease.

\section{Patients and methods}

The trial included 96 out-patients with uncomplicated gonorrhoea and twenty patients hospitalized for recurrent gonorrhoeal infections or complications of the disease. Specimens for direct microscopy and culture were taken at all visits, in men from the urethra and in women from the urethra, cervix, and rectum. The patients were asked to return weekly for follow-up. The criteria for satisfactory therapeutic results were two consecutive negative follow-up cultures.

\section{OUT-PATIENTS}

24 patients ( 12 men and 12 women) were treated with $2 \mathrm{~g}$. ampicillin ('Doktacillin') with $1 \mathrm{~g}$. probenecid ('Probecid') in a single oral dose. Blood serum levels of ampicillin were determined $2 \mathrm{hrs}$ after treatment.

72 patients ( 36 men and 36 women) received $2 \mathrm{~g}$. ampicillin orally divided into two doses with a 5-hr interval. Serum concentrations of ampicillin were determined in all 72 patients $2 \mathrm{hrs}$ after the first dose of $1 \mathrm{~g}$.,

Received for publication December 10, 1972 and in 24 patients ( 12 men and 12 women) a further determination was done $2 \mathrm{hrs}$ after the second dose, i.e. $7 \mathrm{hrs}$ after the first dose.

\section{IN-PATIENTS}

Twenty patients (11 men and 9 women) were hospitalized. Ten of these had had recurrent positive cultures during the follow-up period and different types of treatment had been tried. All denied further sexaul exposure. The remaining ten patients were admitted because of complications of the disease (Table III). During the first day of treatment $2 \mathrm{~g}$. ampicillin were given orally in the divided dosage. Specimens for bacterial culture were taken before treatment and thereafter at 5 , 12 , and 24 hours. Cultures were also made several times as usual, during the follow-up period. Blood serum levels were determined before treatment and at 5 and $7 \mathrm{hrs}$ after the first dose. In thirteen patients a further specimen was taken at $8 \mathrm{hrs}$. All in-patients had fasted overnight before the start of treatment except two with benign gonococcal septicaemia (Cases 17 and 18) who had to be treated immediately after admission. The patients were not allowed to take any food or drink until $2 \mathrm{hrs}$ after the first dose, and the same applied to the period from $1 \mathrm{hr}$ before the second dose to $2 \mathrm{hrs}$ after.

Bacteriological methods:

Specimens were cultured on Thayer-Martin medium. Sensitivity tests in vitro were performed on all positive cultures. Strains with MICs $\geqslant 0 \cdot 1 \mu \mathrm{g}$. ampicillin per ml. have been denoted less sensitive.

Assay of ampicillin serum levels:

Specimens of serum were assayed by means of the cylinder plate method with Sarcina lutea ATCC 9341 as the test organism (Grove and Randall, 1953). Pooled human serum was used as a diluent for the samples and standard. The serum specimens were deep frozen immediately and stored at $-20^{\circ} \mathrm{C}$. until they were analysed.

\section{Results}

OUT-PATIENTS

The results of treatment in relation to the dosage 
schedules and MIC values of ampicillin for $N$. gonorrhoeae are shown in Table I. Three patients ( 1 man and 2 women) did not return for follow-up. Four patients ( 2 men and 2 women) had a positive culture at the first follow-up and one man at the second. Follow-up data as well as the antibiotic serum levels attained in these five 'therapeutic failures' are presented in Table II. Less sensitive gonococci (MIC $\geqslant 0.1 \mu \mathrm{g}$. ampicillin per ml.) were isolated in twenty patients. Two did not return for follow-up. One patient had a positive culture at the first follow-up and is the first patient in Table II. The remaining seventeen were negative in the bacteriological tests. The ampicillin serum levels in the patients harbouring less sensitive gonococci are indicated in the Figure as well as all the individual serum levels of patients treated with the ampicillin schedules. Not unexpectedly there was a wide range of recorded serum levels. What should be noted in particular is that patients with a rather low serum concentration, i.e. $<2.5 \mu \mathrm{g} . / \mathrm{ml} .2 \mathrm{hrs}$ after the first dose had an adequate level $2 \mathrm{hrs}$ after the second dose. On the other hand, those with a high serum level on the first occasion may have a low level on the second. The well-known fact that higher serum levels of ampicillin are attained in combination with probenecid was also confirmed in this study.

\section{IN-PATIENTS (Table III, opposite)}

In the hospitalized patients, it was possible to perform a more extensive study with repeated bacterial cultures and determinations of ampicillin serum levels during the first day of treatment. Of ten patients with repeatedly positive cultures before hospitalization, two had negative cultures on admission. However, one of these (Case 13) had a positive culture 12 hours after the initiation of treatment. While three patients had a positive culture $5 \mathrm{hrs}$ after the first dose, only Case 13 had a positive culture later than $5 \mathrm{hrs}$ after starting treatment. The male patients with complications had negative

TABLE I Results of treatment in the 96 out-patients in relation to in vitro senitivities of the $\mathrm{N}$. gonorrhoeae

\begin{tabular}{|c|c|c|c|c|c|c|c|c|}
\hline \multirow{2}{*}{ Treatment } & \multirow{2}{*}{$\operatorname{Sex}$} & \multirow{2}{*}{ 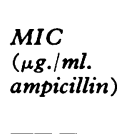 } & \multicolumn{6}{|c|}{ Follow-up cultures (No. of patients) } \\
\hline & & & Defaulted & One & Two or more & First & Second & Total \\
\hline $\begin{array}{l}2 \mathrm{~g} \text {. ampicillin }+1 \mathrm{~g} . \\
\text { probenecid orally in } \\
\text { single dose }\end{array}$ & $\begin{array}{l}\text { M } \\
\text { F }\end{array}$ & $\begin{array}{l}<0.1 \\
\geqq 0.1 \\
<0 \cdot 1 \\
\geqq 0 \cdot 1\end{array}$ & & $\begin{array}{l}1 \\
1 \\
1 \\
1\end{array}$ & $\begin{array}{l}7 \\
1 \\
7 \\
2\end{array}$ & $\begin{array}{l}1 \\
1 \\
1\end{array}$ & & $\left.\begin{array}{l}9 \\
3 \\
9 \\
3\end{array}\right\} 24$ \\
\hline Total & & & 3 & 8 & 80 & 4 & 1 & 96 \\
\hline
\end{tabular}

TABLE II Ampicillin serum levels, in vitro sensitivities of gonococci and follow-up data for the 5 patients with positive follow-up cultures

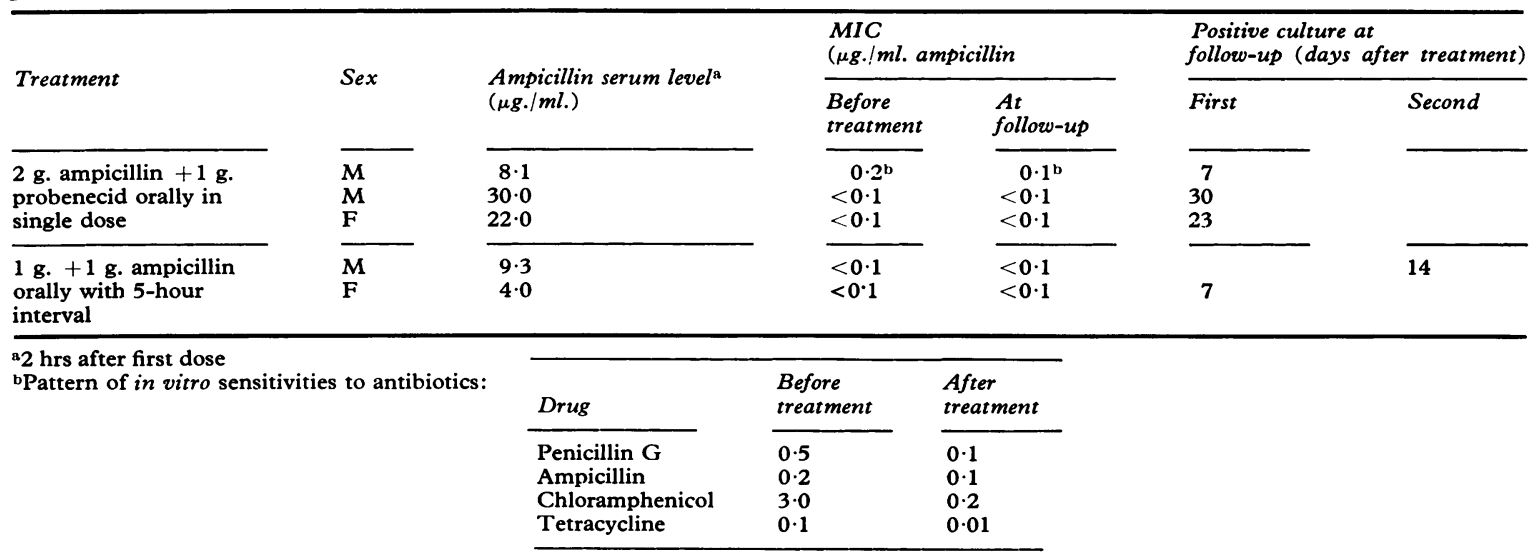



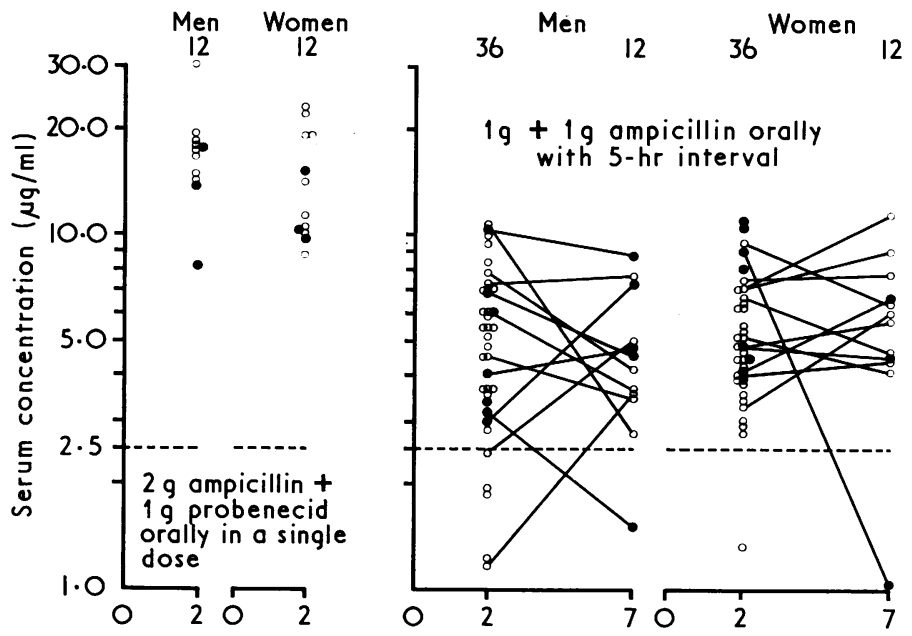

Hours

FIGURE Blood serum levels after oral administration of ampicillin $O$ patients harbouring sensitive strains $(M I C<0 \cdot 1 \mu g$. ampicillin/ $m l$.)

patients harbouring less sensitive strains $(M I C \geqslant 0 \cdot 1$ ug. ampicillin/ml.)

TABLE III Findings in 20 patients hospitalized for gonorrhoea and treated with $2 g$. ampicillin orally in a divided dose with an interval of $5 \mathrm{hrs}$

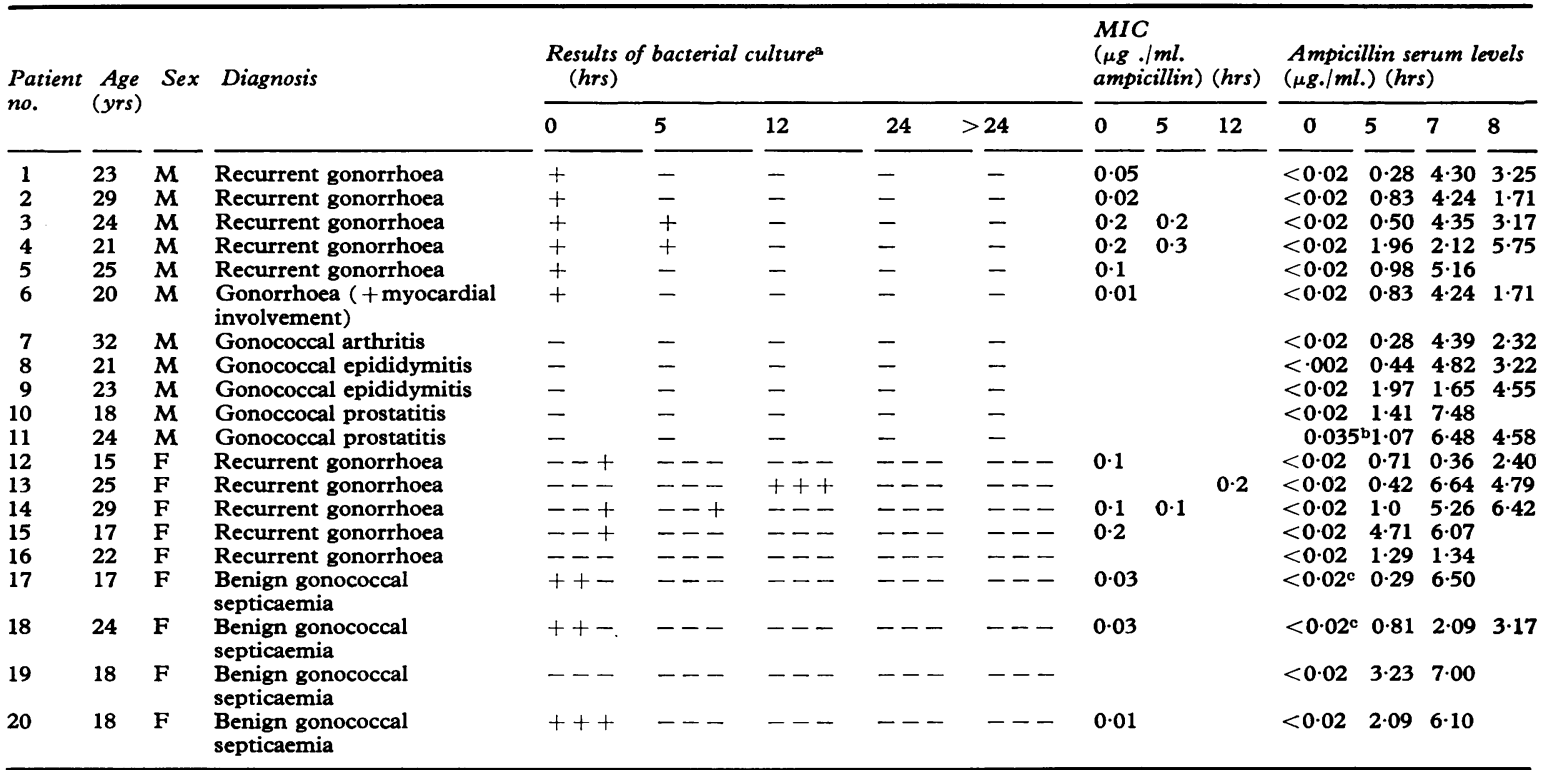

aSamples taken from urethra in men; from urethra, cervix, and rectum in women

bAmpicillin treatment the day before

eNonfasting 
cultures after admission with the exception of Case 6 who had myocardial involvement and whose culture was positive before starting treatment. The four women with benign gonococcal septicaemia were all negative $5 \mathrm{hrs}$ after the first dose. Seven of the thirteen in-patients in whom $N$. gonorrhoeae was isolated harboured strains with decreased sensitivity to ampicillin; three of these seven (Cases 3, 4, and 14) had a positive culture at $5 \mathrm{hrs}$ and one (Case 13) at $12 \mathrm{hrs}$. A wide range of serum levels was noted among the in-patients too, the figures at $7 \mathrm{hrs}$ varying from 0.36 to $7.48 \mu \mathrm{g}$. $/ \mathrm{ml}$. In thirteen patients serum levels of ampicillin were determined also at $3 \mathrm{hrs}$ after the second dose, and it was found that five had their highest serum concentration on this occasion.

\section{Discussion}

Earlier studies of patients with uncomplicated gonorrhoea treated with oral ampicillin have shown a low percentage of therapeutic failures both when the strains have been sensitive and less sensitive to the antibiotic (Eriksson and Wallmark, 1972). This has been true in particular of the one-day dosage regimen. In a study of healthy volunteers, a prolongation of the duration of ampicillin serum levels achieved by the addition of probenecid or by dividing the dose into two equal portions with a $5-\mathrm{hr}$ interval was proved to be of therapeutic importance (Eriksson, 1971b). Fluker and Hewitt (1969) combined high dosage procaine penicillin with ampicillin and obtained better results in the treatment of gonorrhoea, which may have been due to a prolongation of the plateau serum level of penicillin. Out-patients are a hetereogeneous group from the point of view of the amount and time of the last intake of food. Some have an empty stomach on arrival at the clinic, while others have recently had a heavy meal, and some are under the influence of alcohol and/or narcotics. It has been reported, however, that oral ampicillin is well absorbed and that food has only a minor effect on the level of ampicillin in normal young men (Klein and Finland, 1963). The in-patients were more homogeneous in this respect, as they had all been fasting overnight with the exception of Cases 17 and 18.

Wide variation in serum values is not characteristic of oral administration only. Keys, Halverson, and Clarke (1969) reported a wide range of serum values when the antibiotics used in the treatment of gonorrhoea were injected. In addition, they found that several values for penicillin $G$ and ampicillin were particularly low. The last column in Table III shows that in five patients the highest recorded serum level occurred later than 2 hours after drug administration. This is in accordance with the findings of Johnson, Kvale, Afable, Stewart, Halverson, and Holmes (1970), who found the peak serum level at $3 \mathrm{hrs}$ when oral ampicillin was administered with or without probenecid. A single determination of the antibiotic serum level is therefore of dubious value as the absorption process differs widely in respect of time from patient to patient.

The perpetual question in the treatment of patients with gonorrhoea is whether those with a positive culture at follow-up are therapeutic failures or re-infections. Graham, Greenblatt, and Cannefax (1945) reported that 86 per cent. (18 of 21) of recurrences within the first 5 days were treatment failures. Johnson and others (1970) found 21 of 22 recurrences within 3 days of treatment were treatment failures. Generally the longer the time that has elapsed after treatment, the greater is the risk of a positive culture being in fact a new infection.

All five out-patients with a positive culture at follow-up denied further sexual exposure during the interim (Table II). The strains of $N$. gonorrhoeae isolated were fully sensitive to ampicillin both before treatment and at follow-up except in one man. But in this case the difference in pattern of the in vitro sensitivities to the antibiotics tested was such that it is very likely that there may have been two different strains involved. One man did not return for followup until 30 days and one woman until 23 days after treatment. Because of the increasing likelihood of re-infection with the passage of time, there is strong reason to suspect re-infection in these two patients. Furthermore, the serum levels estimated in these two subjects were 30 and $22 \mu \mathrm{g}$. ampicillin per $\mathrm{ml}$. respectively. The man with a negative culture at the first follow-up but a positive one at the second follow-up 14 days after treatment had also had a sufficiently high serum concentration of ampicillin $(9.3 \mu \mathrm{g} . / \mathrm{ml}$.) to suggest that he had a new infection. Only one female patient infected with fully sensitive gonococci showed a positive culture at the first follow-up within one week. This patient had an ampicillin serum level $(4.0 \mu \mathrm{g} . / \mathrm{ml}$. $) 2 \mathrm{hrs}$ after the first dose, which made it uncertain whether a relapse or re-infection was involved. On the other hand, patients infected with less sensitive gonococci and in whom low serum concentrations were obtained (see Figure) did meet the requirement for satisfactory treatment, i.e. at least two consecutive negative follow-up cultures. Thus a true treatment failure may have occurred in only one patient or perhaps not at all among the out-patients in this trial. The rapid disappearance of the gonococci in the ten patients hospitalized for relapsing gonorrhoea (Table 
III), with only one female patient having a positive culture later than $5 \mathrm{hrs}$ after the initiation of treatment, indicates that at least some of these patients had been re-infected and should not have been recorded as treatment failures.

\section{Summary}

Ampicillin serum levels have been determined in 116 patients with gonorrhoea. 96 were out-patients treated for uncomplicated gonorrhoea: 24 (12 men and 12 women) with a single oral dose of $2 \mathrm{~g}$. ampicillin combined with $1 \mathrm{~g}$. probenecid and 72 (36 men and 36 women) with $2 \mathrm{~g}$. ampicillin orally in a divided dose with a $5-\mathrm{hr}$ interval. Twenty patients (11 men and 9 women) were hospitalized, either for recurrent positive cultures despite repeated treatment or for complications of the disease. The in-patients were given the divided dose regimen of ampicillin and, in addition to the determination of ampicillin serum levels had repeated cultures during the first $24 \mathrm{hrs}$. Only three of these patients showed positive cultures in specimens taken $5 \mathrm{hrs}$ after the first dose, one patient was positive at $12 \mathrm{hrs,} \mathrm{while}$ all other cultures were negative at $5 \mathrm{hrs}$ and remained so. No correlation was found in the trial between low serum levels of ampicillin and 'treatment failures', even in those cases harbouring strains of gonococci with reduced sensitivity to ampicillin.

I am indebted to Dr. G. Wallmark, Södersjukhuset, for the bacteriological work, and to Mr. L. Magni of the Research Laboratories, Astra, Södertälje, for the serum level estimations.

\section{References}

ERIKsson, G. (1970a) Acta derm.-venereol. (Stockh.), 50, 451

- (1970b) Ibid., 50, 461

(1971a) Ibid., 51, 305
- (1971b) Ibid., 51, 467

and WALlMARK, G. (1972) Ibid., 52, 419

FlukeR, J. L., and HewitT, A. B. (1969) Brit. F. vener. Dis., 45, 317

Graham, W. E., Greenblatt, R. B., and Cannefax, G. R. (1945) Vener. Dis. Inform., 26, 105

Grove, D. C., and Randall, W. A. (1955) 'Assay Methods of Antibiotics. A Laboratory Manual', p. 14. Medical Encyclopedia Inc., New York

Johnson, D. W., Kvale, P. A., Afable, V. L., Stewart, S. D., Halverson, C. W., and Holmes, K. K. (1970) New Engl. f. Med., 283, 1

Keys, T. F., Halverson, C. W., and Clarke, E. J., Jr. (1969) f. Amer. med. Ass., 210, 857

Klein, J. O., and Finland, M. (1963) Amer. F. med. Sci., 245, 544

Ampicilline, taux sérique et résultats du traitement dans la gonococcie

\section{SOMMAIRE}

Chez 116 gonococciques, on a établi les taux sériques d'ampicilline. 96 malades consultaient pour une gonococcie non compliquée: 24 (12 hommes et 12 femmes) furent traités par une dose unique buccale de $2 \mathrm{~g}$ d'ampicilline associée à $1 \mathrm{~g}$ de probénécide, et 72 (36 hommes et 36 femmes) par $2 \mathrm{~g}$ d'ampicilline buccale pris en doses séparées par 5 heures d'intervalle. Vingt malades (11 hommes et 9 femmes) furent hospitalisés soit pour des cultures de nouveau positives malgré la répétition du traitement, soit pour des complications de la maladie. Les malades hospitalisés reçurent l'ampicilline en doses répétées; outre la recherche des taux sériques de l'ampicilline, des cultures répétées furent pratiquées pendant les premières 24 heures. Trois malades seulement eurent des cultures positives dans les échantillons pris cinq heures après la première administration, un malade fut positif à la l2ème heure alors que toutes les autres cultures furent négatives à la 5ème heure et le restèrent. Au cours de cet essai il ne fut pas trouvé de corrélation entre des taux sériques faibles d'ampicilline et les échecs thérapeutiques, même dans les cas où il s'agissait de souches de gonocoques présentant une sensibilité diminuée à l'ampicilline. 